Terbit online pada laman web jurnal: http://journal.isas.or.id/index.php/JASENS

\begin{tabular}{c} 
JOURNAL OF APPLIED SMART ELECTRICAL \\
NETWORK AND SYSTEMS (JASENS) \\
\hline ISAS
\end{tabular}

\title{
Optimasi Sistem Photovoltaik Menggunakan Konverter Cuk Berbasis Metode Simple Perturb and Observe
}

\author{
Tatit Sulis ${ }^{1}$, Fathoni $^{2}$, Ratna Ika Putri ${ }^{3}$ \\ 1,2, ${ }^{3}$ Teknik Elektronika, Teknik Elektro, Politeknik Negeri Malang \\ ${ }^{1}$ tatitsulis96@gmail.com*, ${ }^{3}$ ratna.ika@polinema.ac.id
}

\begin{abstract}
Considering that Indonesia is a tropical country, the availability of solar energy is abundant during the dry season which lasts for 6 months. Photovoltaic can be used as a source of electrical energy in remote areas that are still not reached by PLN. The circuit of choice was chosen because it is able to lower and increase the source voltage of the 200WP photovoltaic. The advantage of the cuk converter is that it is able to reduce the ripple at the PV output which can cause the voltage to reach a constant long time. The well-known method is the perturb and observation (P\&O) method in the P\&O method, PWM is used to control the converter and control the desired voltage. Based on the test, the input voltage of $12 \mathrm{~V}$ power supply with a duty cycle of $10 \%$ produces a voltage of $1.99 \mathrm{~V}$. Meanwhile, the test results for the $12 \mathrm{~V}$ power supply input, with a duty cycle of $60 \%$, produce a voltage of $11.59 \mathrm{~V}$. So that the application of $\mathrm{P} \& \mathrm{O}$ on the choke is considered to be quite effective in the photovoltaic system with fairly stable results and an average output voltage of 23,848 Volts.
\end{abstract}

Keywords: Photovoltaic, Cuk Converter, PWM, P\&O.

\begin{abstract}
Abstrak
Mengingat indonesia adalah negara tropis maka ketersediaan energi matahari yang cukup melimpah pada saat musim kemarau yang berlangsung selama 6 bulan. Photovoltaik dapat digunakan sebagai sumber energi listrik di daerah terpencil yang masih belum terjangkau oleh PLN. Rangkaian konverter cuk dipilih karena mampu menurunkan dan menaikkan tegangan sumber dari photovoltaik 200WP. Kelebihan cuk konventer yaitu mampu mengurangi ripple pada keluaran PV yang dapat menyebabkan tegangan akan lama mencapai konstan. Metode yang terkenal adalah metode perturb and observe $(\mathrm{P} \& \mathrm{O})$ dalam metode P\&O, PWM digunakan untuk mengontrol konverter dan mengontrol tegangan yang di inginkan. Berdasarkan hasil pengujian, tegangan masukan power supply $12 \mathrm{~V}$ dengan duty cycle $10 \%$ menghasilakan tegangan $1.99 \mathrm{~V}$. Sementara hasil pengujian masukan power supply $12 \mathrm{~V}$, dengan duty cycle $60 \%$ menghasilkan tegangan $11.59 \mathrm{~V}$. Sehingga penerapan $P \& O$ pada konverter cuk dirasa cukup efektif pada sistem photovoltaik dengan hasil yang cukup stabil dan rata-rata keluaran tegangan 23,848 Volt.
\end{abstract}

Kata kunci: Photovoltaik, Konverter cuk, PWM, P\&O.

Diterima Redaksi : 24-05-2021 | Selesai Revisi : 21-06-2021 | Diterbitkan Online : 30-06-2021

\section{Pendahuluan}

Teknologi PV (Photovoltaik) di dunia industri indonesia sudah banyak digunakan[1], Mengingat indonesia merupakan negara tropis sehingga ketersediaan energi matahari yang cukup melimpah[9]. Photovoltaik dapat digunakan sebagai sumber energi listrik di daerah yang belum terjangkau PLN[2], daya yang dihasilkan oleh photovoltaik dipengaruhi oleh intensitas cahaya matahari, suhu matahari, faktor geografi[3]. Maka diperlukan sistem kontrol yang mampu melacak titik daya maksimum[10]. Teknik MPP (Maximum Power Point) adalah sebuah teknik mendapatkan daya maksimum disetiap kondisi yang berbeda - beda[4].
Beberapa metode telah dikembangkan untuk menentukan titik daya maksimal, salah satunya metode perturb and Observe $(\mathrm{P} \& \mathrm{O})$, metode $\mathrm{P} \& \mathrm{O}$ mempunyai algoritma untuk mencapai daya yang maksimal. Metode P\&O bekerja dengan cara mencari gangguan pada tegangan atau arus pada daya keluaran PV dan mengevaluasi daya keluaran PV dengan siklus pertubasi sebelumnya[5] serta metode P\&O memiliki kemampuan self tuning dapat mencapai daya maksimum[6].

Untuk dapat mencapai daya maksimum dengan cara mengatur duty cycle pada dc-dc converter[11], dengan menggunakan rangkaian cuk converter lalu rangkaian cuk converter diaplikasikan pada PV[8]. Cuk converter mempunyai beberapa kelebihan yaitu salah satunya 
mampu mengurang ripple pada keluaran PV yang dapat yang didapat sekarang dengan nilai daya yang menyebabkan tegangan akan lama mencapai konstan[7]. sebelumnya. Dari flowchart algoritma P\&O seperti pada

\section{Metode Penelitian}

\subsection{Diagram Blok}

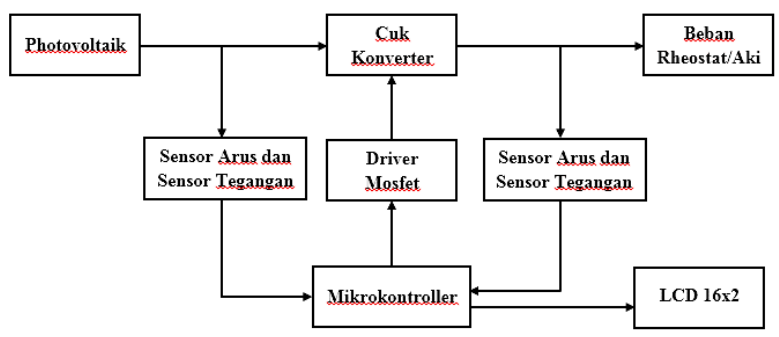

Gambar 1. Diagram Blok

Blok diagram sistem ditunjukkan pada Gambar 2 yaitu Photovoltaik mengkonversi energi matahari menjadi energi listrik yang berupa arus dan tegangan. Arus dan tegangan akan masuk ke konverter cuk. Dikarenakan hasil arus dan tegangan dari photovoltaik tidak stabil, tergantung intensitas matahari, untuk memperoleh daya yang maksimum maka digunakan metode Perturb and Observe ( $\mathrm{P} \& \mathrm{O})$ untuk mengatur duty cycle pada konverter cuk. Ketika tegangan yang dihasilkan dari photovoltaik lebih besar dari keluaran yang diinginkan maka konverter cuk akan menaikkan duty cycle untuk menurunkan keluaran sesuai dengan keluaran yang diinginkan, begitupun sebaliknya ketika keluaran kurang dari keluaran yang diinginkan. Konverter cuk akan menurunkan duty cycle agar keluaran naik sesuai dengan keluaran yang diinginkan. Hal ini terjadi terus menerus hingga keluaran yang diinginkan menjadi konstan. Metode P\&O yang ada didalam mikrontroler akan mengatur nilai duty cycle yang dibutuhkan oleh konverter cuk berdasarkan arus dan tegangan yang dibaca oleh sensor arus dan tegangan. Hasil masukan dan keluaran ditampilkan di LCD $16 \times 2$.

\subsection{Perancangan Perturb and Observe}

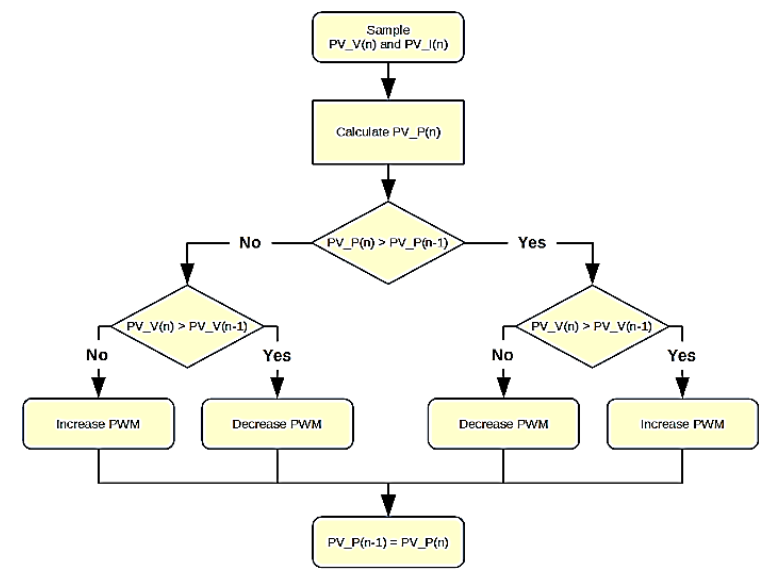

Gambar 2. Flowchart P\&O Gambar 2, Sample PV_V(n) and PV_I(n), merupakan pembacaan tegangan dan arus yang dihasilkan oleh PV sehingga dapat di kalkulasikan menjadi daya PV_P(n). Jika telah mencapai titik daya yang diinginkan maka akan mengoreksi tegangan PV_V(n). Jika tegangan kurang dari yang diinginkan maka PWM dinaikkan. Jika tegangan lebih dari yang diinginkan maka PWM diturunkan.

\subsection{Perancangan Driver Mosfet}

Untuk mengaktifkan mosfet pada konverter cuk maka diperlukan driver mosfet untuk mengaktifkannya. Perancangan rangkaian driver mosfet menggunakan optocoupler PC817 seperti pada Gambar 4. Driver mosfet berfungsi untuk mengaktifkan switching mosfet dengan cara menghubungkan driver mosfet antara keluaran pin mikrokontroler dengan pin gate mosfet.

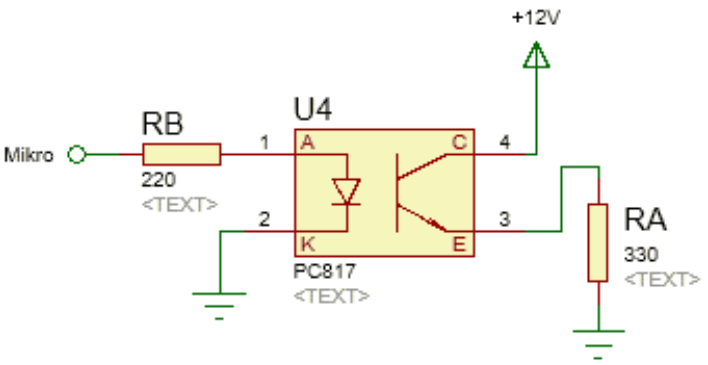

Gambar 3. Rangkaian Driver Mosfet

Untuk mengetahui besaran komponen yang digunakan RA dan RB pada rangkaian driver mosfet maka dapat menggunakan persamaan yaitu :

Perhitungan Mencari Nilai Hambatan RA

$$
\begin{aligned}
& R A=\frac{V c c-V c e}{I f} \\
& R A=300 \Omega
\end{aligned}
$$

Pada rangkaian Driver Mosfet menggunakan resistor $330 \mathrm{Ohm}$ karena terdapat dipasaran.

Perhitungan Mencari Nilai Hambatan RB

$$
\begin{aligned}
R B & =\frac{V c c-V f}{I f} \\
& =170 \Omega
\end{aligned}
$$

Pada rangkaian Driver Mosfet menggunakan resistor 220 Ohm karena terdapat dipasaran.

\subsection{Perancangan Konverter cuk}

Konverter cuk merupakan salah satu jenis rangkaian penaik atau penurun tegangan yang memiliki karakteristik seperti rangkaian buckboost. Hasil keluaran tegangan output mempunyai polaritas yang berkebalikan dengan tegangan input.

Metode perturb and observe $(\mathrm{P} \& \mathrm{O})$ merupakan metode yang bekerja dengan cara membandingkan nilai daya 


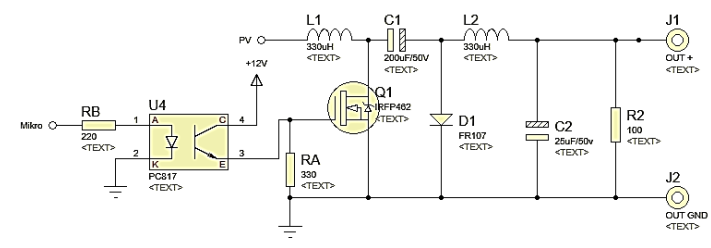

Gambar 4. Rangkaian Konverter cuk

Untuk dapat mengetahui besaran komponen yang digunakan seperti mosfet, duty cycle

Perhitungan Nilai Duty Cycle Minimal dan Maksimal

$$
\begin{array}{ll}
V o & =\operatorname{Vin} \frac{D}{1-D} \\
24-24 D & =36 D \\
24 & =60 D \\
D & =0.4
\end{array}
$$

Perhitungan Nilai Induktor

$$
\begin{aligned}
& L 1=\frac{\operatorname{Vout}(1-D) T s}{\Delta \mathrm{IL} 1} \\
& L 1=232.258 u H
\end{aligned}
$$

Didapat nilai inductor sisi input dan output sebesar $232 \mu \mathrm{H}$, maka inductor yang digunakan pada rangkaian sebesar $330 \mu \mathrm{H}$.

Perhitungan Nilai Kapasitor

$C 1=\frac{\text { Iout } \times D \times T s}{\Delta \mathrm{Vcc}}$

$C 1=10.7457 u F$

Didapat nilai kapasitor sebesar $10 \mu F$, Maka kapasitor yang digunakan $20 \mu F$ sesuai dengan yang ada di pasaran.

Perhitungan Nilai Kapasitor Filter

$$
\begin{aligned}
C 2 & =\frac{\Delta \mathrm{IL} 2}{\Delta \mathrm{Vcc}} \times \frac{1}{8 F s} \\
C 1 & =20.1612 u F
\end{aligned}
$$

Didapatkan nilai kapasitor sebesar $20.16 \mu \mathrm{F}$, maka kapasitor yang digunakan $35 \mu \mathrm{F}$ sesuai dengan yang ada di pasaran.

\subsection{Perancangan Sensor Arus}

sensor arus ACS712 merupakan sebuah modul sensor untuk mengukur arus baik arus AC maupun arus DC. Pemilihan sensor ACS712 karena memiliki arus maksimal 5A dan dengan jangkauan tegangan keluaran minimal $1 \mathrm{~V}$. sedangkan alat membutuhakan arus maksimal tidak sampai 5A. jadi penggunaan sensor ACS712 sangat tepat serta sangat mudah di dapat dan terjangkau di pasaran. Sensitifitas sensor ACS712 ini memiliki arus sebesar 100mV/A.

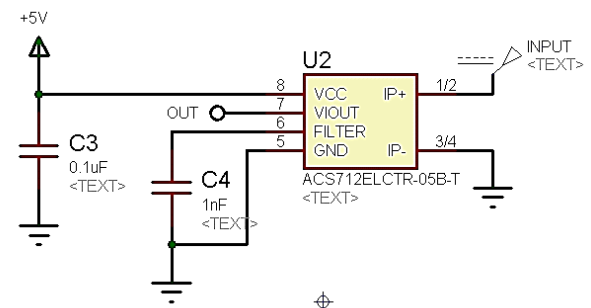

Gambar 5. Rangkaian Sensor Arus

\subsection{Perancangan Sensor Tegangan}

Sensor tegangan berfungsi untuk mendeteksi tegangan keluaran PV. Keluaran dari sensor terhubung ke pin analog mikro. Tegangan dari PV yang akan di ukur memiliki tegangan $1 \mathrm{~V}-36 \mathrm{~V}$. Tegangan keluaran sensor yang terhubung mikro memiliki tegangan $0 \mathrm{~V}-4.8 \mathrm{~V}$ sebagai masukan pin analog mikrokontroler.

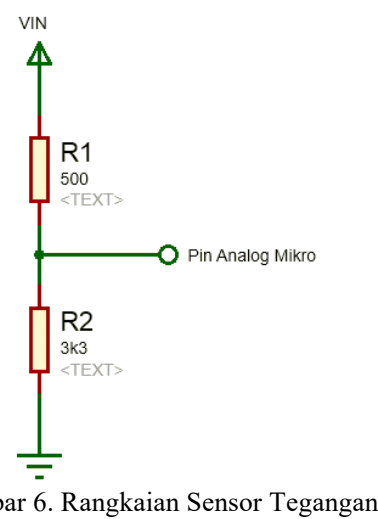

Untuk menegatahui besaran komponen yang digunakan $\mathrm{R} 1$ dan $\mathrm{R} 2$ pada rangkaian driver mosfet maka dapat menggunakan persamaan yaitu :

Perhitungan Arus Maksimal Pada Beban Resistor

$$
\begin{aligned}
& I_{\text {max }}=\frac{P}{V \max } \\
& I_{\text {max }}=6 \mathrm{~mA}
\end{aligned}
$$

Perhitungan Nilai Resistansi Total Kedua Resistor

$$
\begin{aligned}
\text { Rtotal }_{\text {min }} & =\frac{V \max }{I \max } \\
\text { Rtotal }_{\min } & =600 \Omega
\end{aligned}
$$

Perhitungan Nilai Resistansi R1 dan R2

$$
\begin{aligned}
& \text { Vout }=\frac{R 2}{R 2+R 1} \times \text { Vin } \\
& 5=\frac{R 2}{R 2+R 1} \times 36 \\
& 5 R 1+5 R 2=30 R 2 \\
& 5 R 1=25 R 2 \\
& \text { Jika } R 1=600 \\
& R 2=(5 \times 600)
\end{aligned}
$$




\section{Hasil dan Pembahasan}

\subsection{Pengujian Sensor Tegangan}

Pengujian ini dilakukan untuk mengetahui kemampuan kerja dari sensor tegangan sebelum sensor digunakan sebagai alat ukur tegangan pada rangkaian konverter cuk. Pengujian dilakukan dengan cara melewatkan Pada saat tegangan PV kurang dari yang di butuhkan, tegangan dari sumber tegangan yaitu DC power supply maka tegangan akan dinaikkan. Tetapi pada saat ke dalam sebuah rangkain sensor tegangan. Nilai yang tegangan keluaran PV lebih besar dari yang di butuhkan, terbaca pada sensor tegangan selanjutnya akan maka tegangan akan diturunkan.

dibandigkan dengan alat ukur tegangan lainnya yaitu AVO meter.

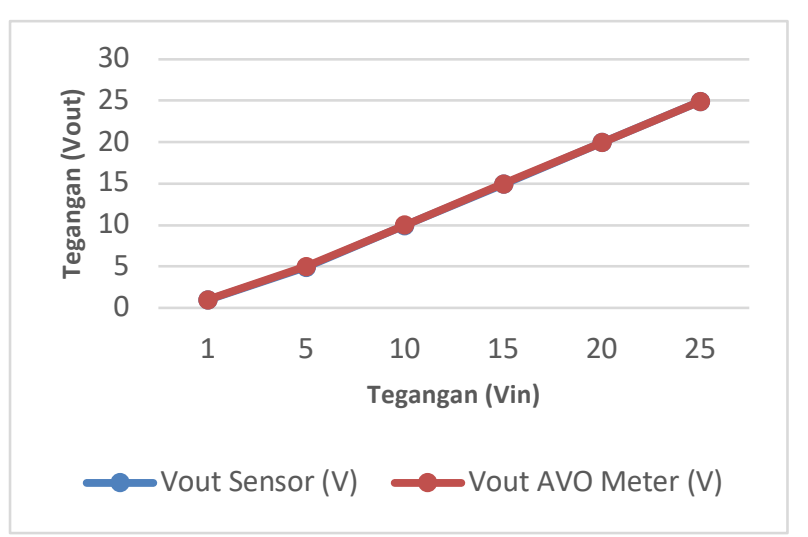

Gambar 7. Grafik Pengujian Sensor Tegangan Berdasarkan ppengujian sensor tegangan maka dapat tegangan output rangkaian konverter cuk akan disimpulkan pengukuran menggunakan sensor tegangan bertambah besar, sedangkan jika duty cycle bertambah dengan menggunakan multimeter terlihat linier. Ini kecil maka tegangan output rangkaian konverter cuk berarti sensor tegangan dapat dijadikan patokan data akan bertambah kecil. untuk penggunaan metode perturb and observe $(\mathrm{P} \& \mathrm{O})$.

\subsection{Pengujian Sensor Arus}

3.4 Pengujian Konverter cuk Dengan Input Dibawah 12 Volt

Pengujian ini dilakukan untuk mengetahui kemampuan Pengujian ini dimaksudkan untuk melihat kemampuan kerja dari sensor arus ACS712 sebelum sensor konverter cuk yang menggunakan metode P\&O untuk digunakan sebagai alat ukur arus pada rangkaian menghasilkan keluaran tegangan dan arus. Pengujian konverter cuk. Pengujian dilakukan dengan cara dilakukan dengan cara menguhungkan inputan PV yang melewatkan arus dari sumber tegangan yaitu DC power dihubungkan dengan beban rheostat dengan beban supply ke dalam sebuah rangkain sensor arus yang sudah $101,6 \Omega$.

diberi beban. Nilai yang terbaca pada sensor arus selanjutnya akan dibandigkan dengan alat ukur arus lainnya yaitu AVO meter.

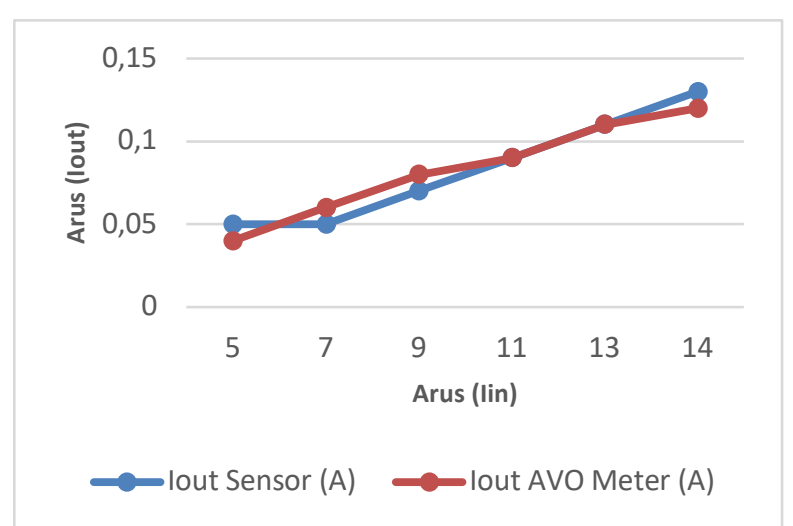

Gambar 8. Grafik Pengujian Sensor Arus

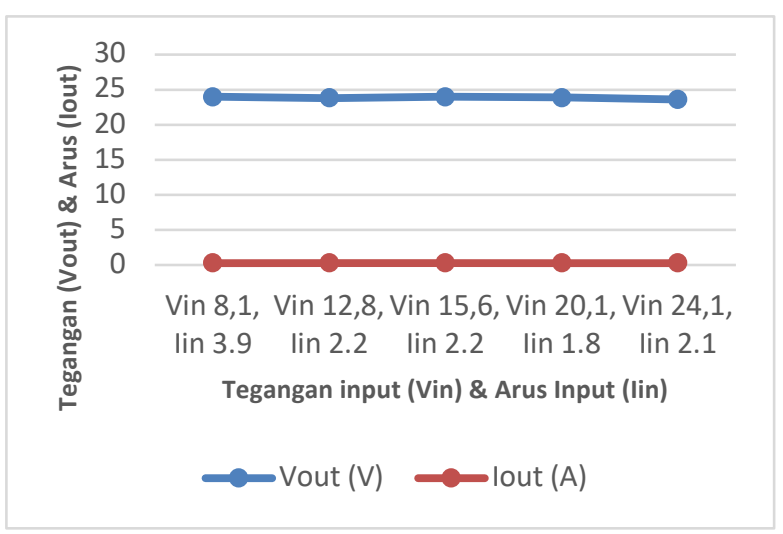

Gambar 10. Grafik Pengujian Konverter cuk dengan Input Dibawah 12 Volt

Berdasarkan hasil pengujian Rangkaian berhasil menstabilkan keluaran tegangan sesuai dengan tegangan

Journal of Applied Smart Electrical Network and Systems (JASENS) 
yang sudah dirancang yaitu 24V. Hal ini terjadi karena Pengujian dilakukan dengan cara mengambil data metode $P \& O$ bekerja mengkompensasi kekurangan atau keluaran photovoltaik yang dihubungkan dengan beban kelebihan daya dengan cara memperbesar atau rheostat, waktu pengujian dilakukan pada pukul 11.00 memperkecil nilai PWM yang akan digunakkan untuk WIB hingga 15.00 WIB. Beban rheostat akan diubah menaikkan atau menurunkan tegangan dan daya. ubah dengan range beban $110,7 \Omega$ hingga $152,7 \Omega$.

\subsection{Pengujian Konverter cuk Tanpa Metode P\&O}

Berdasarkan hasil pengujian didapatkan keluaran Pengujian dilakukan dengan cara mengambil data tegangan rangkaian $24 \mathrm{~V}$, dengan rata-rata keluaran keluaran photovoltaik yang dihubungkan dengan beban tegangan 23,848 Volt dengan rata-rata arus 0,2 Ampere. rheostat. Waktu pengujian dilakukan antara pukul $11.00 \mathrm{Hal}$ ini terjadi karena metode $P \& O$ bekerja WIB hingga 15.00 WIB. Hal ini dilakukan karena ketika mengkompensasi kekurangan atau kelebihan daya pukul 11.00 WIB hingga 15.00 sinar matahari sangat dengan cara memperbesar atau memperkecil nilai PWM terik sehingga keluaran dari photovoltaik akan yang akan digunakan untuk menaikkan atau maksimal. Beban rheostat akan diubah - ubah dengan menurunkan tegangan.

range beban $110,7 \Omega$ hingga $152,7 \Omega$.

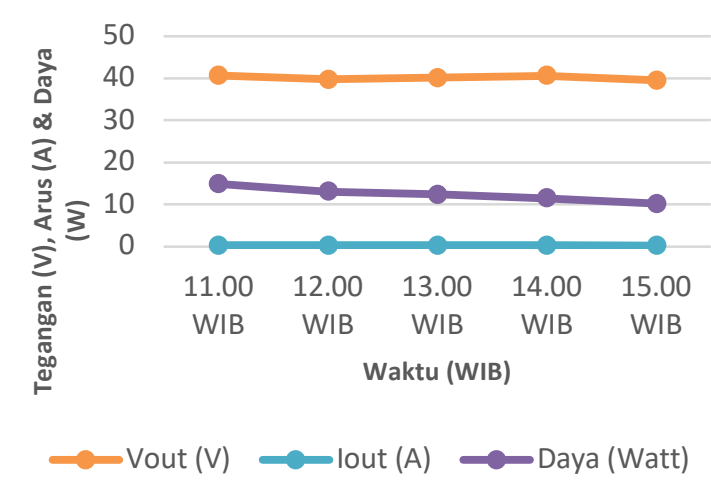

Gambar 11. Grafik Pengujian Konverter cuk Tanpa Metode P\&O

Berdasarkan hasil pengujian didapatkan bahwa tegangan tertinggi bernilai $42,55 \mathrm{~V}$ terjadi pada pukul $11.00 \mathrm{WIB}$ dengan beban bernilai $152,7 \Omega$. Ini menandakan bahwa photovoltaic menerima energi matahari terbaik sehingga mengahasilkan daya yang maksimal. Selama pengambilan data yang dimulai dari pukul 11.00 hingga 15.00 rata - rata tegangan yang dihasilkan oleh photovolaik adalah $40,51 \mathrm{~V}$.

\subsection{Pengujian Konverter cuk Dengan Metode P\&O}

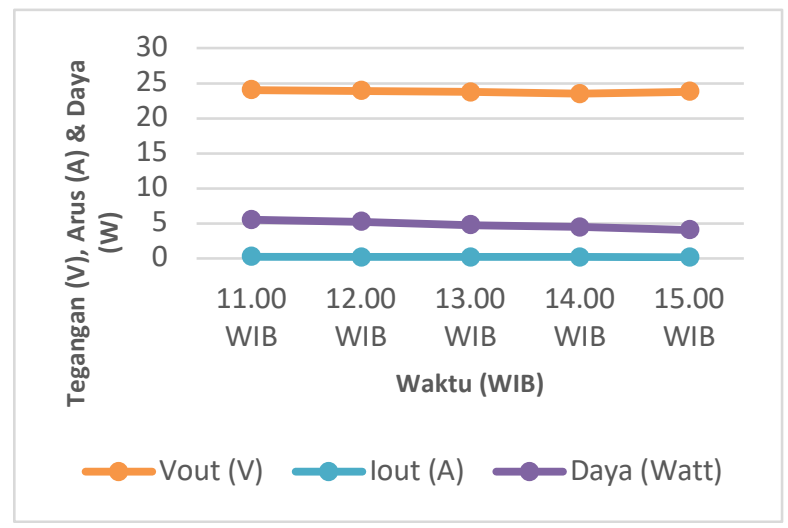

Gambar 12. Grafik Pengujian Konverter cuk Dengan Metode P\&O

\section{Kesimpulan}

Berdasarkan hasil penelitian optimasi sistem photovoltaik menggunakan konverter cuk berbasis simple perturb and observe method dapat diambil kesimpulan, jika tanpa menggunakan metode $P \& O$ maka rata-rata tegangan keluaran 40,3 volt dan rata-rata arus 0,1 Ampere, apabila menggunkan metode $P \& O$ maka rata-rata tegangan keluaran 23,848 volt dan ratarata arus keluaran sebesar 0,2 Ampere. Sehingga penerapan $P \& O$ pada konverter cuk dirasa cukup efektif dengan hasil keluaran yang cukup stabil. Lebar pulse signal PWM pada cuk converter akan berubah apabila tegangan input kurang dari 24 Volt atau lebih dari 24 Volt, sehingga tegangan keluaran Cuk Converter tetap stabil.

\section{Ucapan Terimakasih}

Terima kasih kepada pembimbing di Politeknik Negeri Malang yang telah meluangkan waktu untuk membantu menyelesaikan penelitian ini.

\section{Daftar Rujukan}

[1] Suryoatmojo, H., 2020. Design of Bidirectional DC-DC Cuk Converter for Testing Characteristics of Lead-Acid Battery. Przeglad Elektrotechniczny, 26 (3), pp.114-118.

[2] Fitriah, A, CITEE (Conference on Information Technology and Electrical Engineering), 2019. Implementasi Maximum Power Point Tracking (MPPT) Berbasis Perturb and Observe (P\&O) pada Photovoltaic (PV) dengan Variasi Iradiasi. Yogyakarta, 2425 Juli 2019. FT UGM : Yogyakarta.

[3] Dhuhari, B.C., 2016. MPPT Pada Sistem PV Menggunakan Algoritma Firely P\&O dengan Modified P\&O Konverter Hybrid Cuk Terkoneksi ke Grid Satu Phasa Dibawah Kondisi Partial Shaded, Jurnal Teknik ITS, 5 (2), pp.128-134.

[4] Mohamad, H.L., 2016. Analisis Perbandingan Buck-Boost Converter dan Cuk Converter Dengan Pemicuan Mikrokontroller ATmega8535 Untuk Aplikasi Peningkatan Kinerja Panel Surya, Jurnal Transmisi, 18 (3), pp.137-144.

[5] Fauzi, A., 2018. Perencanaan Maximum Power Point Tracking (MPPT) Dengan Metode Perturb and Observe Pada Panel Surya, Jurnal Transient, 7 (4), pp.918-924.

[6] Utami, S., 2017. Implementasi Algoritma Perturb and Observe Untuk Mengoptimasi Daya Keluaran Solar Cell Menggunakan MPPT, Jurnal Infomatika-Telekomunikasi-Elektronika, 9 (1), pp.92-99.

[7] Safroni, A.L, CITEE (Conference on Information Technology and Electrical Engineering), 2019. Rancang Bangun MPPT Cuk

Journal of Applied Smart Electrical Network and Systems (JASENS) 
Converter Dengan Hill Climbing Pada Wind Turbine Dengan Monitoring IoT. Yogyakarta, 24-25 Juli 2019. FT UGM : Yogyakarta.

[8] Hadyan, P.P.. 2016. Perbaikan Faktor Daya Menggunakan Cuk Converter pada Pengaturan Kecepatan Motor Brushless DC", Jurnal Teknik ITS, 5 (2), pp.156-162.

[9] Erik, T., 2016. Maximum Power Point Tracking dengan Algoritma Perturb and Observe Untuk turbin Angin. Jurnal Ilmiah SETRUM, 5 (2), pp.53-56.

[10]Almanda, D, SEMNASTEK (Seminar Nasional Sains dan Teknologi), 2019. Perbandingan Kinerja Konverter Buck Boost dan Konverter Sepic Sebagai Charger Baterai Berbasis Panel Surya. Jakarta, 16 Oktober 2019. Fakultas Teknik : Universitas Muhammadiyah Jakarta.

[11] Suwito., 2017. Sistem Baterai Charging Pada Solar Energy System dengan Buck Boost Converter untuk Berbagai Tingkat Pencahayaan Di Bandar Udara, Jurnal Teknologi Penerbangan, 1 (1), pp.39-48. 